\title{
Causes of Underachievement in Beginning College Students: It's Complicated
}

\author{
Melissa McNabb
}

\begin{abstract}
Underachievement in many beginning college students in American universities is a problem. In this small-scale ethnographic study at a large Midwestern University, members of a class specifically designed for freshmen and sophomores who underachieved during their first or second year in college (defined as those who accumulated a cumulative GPA of 2.0 or less) were observed and interviewed to determine individual causes of academic underperformance. The personal explanations of these students, the rich commentary of their peer instructor and the teacher of the class, along with the researcher's participant observation and examination of class documents allowed intimate perspectives about why college beginners academically underachieve. This qualitative, ethnographic research shines a light into the dilemma of academic underperformance and uncovers a complicated exegesis of why beginning college students struggle and achieve less than their academic potential.
\end{abstract}

Keywords: underperformance; underachievement; beginning college; academic probation; college freshmen; SAT tests

\section{Introduction}

A student who academically underachieves is intriguing to me and has been for most of my life. This person who can earn A's but does not, who is capable of a gold star, but does not receive one, baffles me. Through ethnographic analysis, this project formally investigates the stories of freshmen and sophomores in college at a large Midwestern University, studying why academically capable people underachieved, as indicated by their cumulative GPS at the end of their first or second, first-year semesters.

The modes of discovery in this project centered on ethnographic observations and interviews with members of a mandatory academic probation class (pseudonym C100). The ultimate goal of this study was to listen to and record personal accounts of academically struggling students and learn from their stories. While considering the essential question of currently enrolled, individual students' institutionalized record of underachievement, preconceived researcher biases swirled in my mind: 1) Is a lack of motivation a cause of academic underachievement? 2) Is a lack of familial model of success in college a cause of underperformance? 3) Is a lack of psychological maturity a cause of underachievement? 4) Is a lack of vision for one's future a cause of underperformance? From these initial queries, a key secondary research question for this project evolved: Are the reasons for a lack of academic success similar in interview participants or particular to each student? 
While considering what innate personal biases I might bring to this project, I recounted LeCompte and Schensul's (1999) remark, "as an ethnographer, my observations and subsequent descriptions and transcriptions are filtered through (my) personal, professional, cultural, and theoretical lenses" (p. 31). Truly I wondered if I were too much of an "education is everything snob" to listen accurately to reasons why one had underachieved in college.

\section{Theoretical Framework}

I have always been curious about the why's of underperforming students; I have often experienced that underperforming students and I are drawn to one another like powerful magnets. My research involving students on academic probation who struggle are prototypes of students across our nation, with similar personal circumstances and issues. Scholar Lev Vygotsky (1978) posited the concept of the scaffolding which provides the key theoretical framework of this research: "there are two parts of a learner's developmental level: the 'actual developmental level' and the 'potential developmental level.' The zone of proximal development is the distance between the actual developmental level as determined by independent problem solving and the level of potential development as determined through problem solving under adult guidance, or in collaboration with more capable peers" (p. 86). The specific class of my research focus, taken by students on probation, offers multiple types of support during a difficult academic time period. A "leg up," as it were, to gain or regain confidence, to learn study skills, or time management skills, or whatever knowledge they lack to "scaffold" their way back to a successful academic career.

Another important piece of the theoretical framework of this ethnographic research regarding the dilemma of underachieving beginning college students is Pierre Bourdieu's (1992) theory of cultural capital and field. To Bourdieu's way of thinking, students' cultural capital encompasses the educational wherewithal she or he brings with them to the college classroom: the ability to possess time management skills, testing capabilities at the college level, and the ability to handle the multi-tasking demands of freedom and responsibility. The bBackground or previous family circumstances contribute to a student's cultural capital and contribute to a beginning college student's ability to succeed in the early stages of college or not. Bourdieu found the idea of the field key to valid ethnographic research (cited in Grenfell, et al., 2012).

Various researchers have studied facets of education to discover elements that present stumbling blocks for beginning college students. Hull-Blanks et al. (2005), Ryland, Riodan, and Brack (1994), and Tinto (1987) make points that "four types of career goals (job related, school related, value related, and unknown) with factors of school retention, academic performance, self-esteem, educational self-efficacy, and school and career commitment" (Hull-Banks et al., 2005, p. 2) are the bases which determine academic success. Many educational researchers and psychologists concur that when beginning college students have job-related goals, they are more successful in school. A mindset of "I don't know what I am doing here," rooted in undetermined goals about majors or the purpose of being in college, often factors into a negative school experience. 
A major issue related to academic success facing beginning college students is caused by the psychosocial elements of social support and maladaptive coping strategies, including binge-drinking and smoking as stress-related coping mechanisms for loneliness and being overwhelmed with the college-level academic workload and time management concerns. DeBerard, Spielmans, and Julka (2004) address these issues and how they affect the first-year cumulative GPA results of freshman students. In a study specifically about loneliness and its effect on beginning college students, J. J. Ponzetti (2012) indicates its possible negative effect on academic success.

There are various landmines that await beginning college students as potential hindrances to their academic success. In reality, many first-year college students experience serious adaptive difficulties which negatively affect their grades. The onslaught of these difficulties in the lives of first-year college students manifest in several negative ways, one being their first semester or first year GPA results. Hickman, Bartholomae, and McKinney (2000) examined the relationship between parenting styles, academic achievement, and adjustment of college freshmen, which resulted in authoritative academic achievement being positively related to student academic adjustment. As well, they showed that positive self-esteem was significantly predictive of social, personal, emotional, goal commitment-institutional, academic, and overall adjustment of traditional college freshmen (p. 2). In a variation on this theme, Hickman, teamed with two other researchers on the same topic (Hickman, Toews, \& Andrews, 2001), further discovered that an authoritative parenting style was positively related to males' initial college grade point average, but not significantly associated with that of females.

Where the great divide regarding underperformance in college falls for many educational researchers is whether underachievement comes from a student ill-prepared for the demands of the rigor of college curriculums (Haycock \& Huang, 2001) or students who do not perform to expected standards because of external issues like self-esteem, perfectionism/procrastination, and an ability or willingness to take risks (Fehrenbach, 1993). A salient point undergirding the work of this study is Coleman and Freedman's 1996 article, which concurs with researcher Megan Balduf as she compiled evidence that "a considerable number of students who either voluntarily or involuntarily leave a 4-year college before graduating have, at some point, been on academic probation" (Balduf, 2009, p. 277). Their point is well taken that students on academic probation, for whatever reasons, are on precarious ground. Through detailed ethnographic analysis of beginning collegiate level academic struggles, this research fills a gap in educational underachievement research by accessing the factors college students themselves attribute to their lack of success. Garfinkel (1967) makes an essential point when he acknowledges, "In observing new scenes, we often use what we ultimately come to know to describe events and meanings that we had initially not understood .... indeed, observation involves continuous processes of such retrospective reinterpretation as the observer shapes into more definitive form what at some earlier point had been hazy, ambiguous, or downright confusing" (as cited in Emerson, Fretz, \& Shaw, 2011, p. 106).

Committed to (participants') meanings and experiences, ethnographers are more attracted by what are "experience-near" as opposed to "experience-distant" concepts; thus, they generally give priority to these meanings over a priori, received 
theories and researchers' assumptions about the salience and import of these background characteristics. Valuing the local and the specific, field researchers look in a focused way at daily life rather than in a broad and sweeping manner at general patterns. (Geertz, 1983, cited in Emerson, Fretz, \& Shaw, 2011, p. 158)

From this ethnographic study's collection of data, with methodological rigor and transparent data, this new, "experience-near" information provides a fresh eye on a serious issue in higher education: that of underachieving beginning college students.

\section{Methodology}

The methodology of this research was carried out from a qualitative, ethnographic perspective, specifically through the lens of classroom ethnography. With an up-close view of underperforming students at the desk level, this data collection through observation and interviews allows a clear presentation of the facts from the proverbial horses' mouths.

This research was collected through the lenses of visual and aural acuity via triangulation of observation in the classroom: watching my participants, the peer instructor, and the teacher conduct themselves on a day-to-day classroom event basis. Deepened through recorded, structured and unrecorded, unstructured conversations with the teacher and peer instructor, disciplined field notes, and a running record of questions that came up during class observations, this method of triangulation served as an objective way to verify hunches and questions that arose. Member checking via emailed transcriptions of interviews identified errors in memory and typos. Indeed, sometimes a participant clarified what they "meant" to say at a certain point in the interview, which gave validity to the value and intent of the participant's explanation. In the case of the teacher/whole class observation field notes included here, the teacher of the class member checked the recorded notes for accuracy. "Knowing how to separate detail from trivia ... and using rigorous methods to validate observations" is important (Patton, 1990, pp. 260261). As Professor Lucinda Carspecken at Midwestern University made clear in a class lecture on April 1, 2014, "the rationale for triangulation (is that) the more perspectives we have on any social phenomenon, the more complete a picture we will have." The analysis of the entire project required consideration of all of the data collected as well as triangulation and member checking of student interviews and teacher interviews to achieve credible findings. This is because, as LeCompte and Schensul (1999) remind uus, "themes, patterns, and ideas of interest in a study do not just emerge magically from fieldnotes" (p. 46).

In writing about each participant and choosing the specific excerpts to include as authentically representative of their academic probation experience, I coded specifically according to particularities of behavior. "Specificity in purpose and good coding for recording instances of behavior are important to producing research that is trustworthy" (Merriam, 2009, p. 120). Elements of the framework I establish in my research to promote trustworthiness are writing copious field notes with attention to timeliness and detail. I focused closely on how the atmosphere in the room felt, what the students were doing, what the context of the lesson was, what dominant power structures were present in the particular observation situation, and what prior biases might have existed in me toward the participant and the environment. At times I noticed that my decade as a teacher gave me a certain "insider" researcher viewpoint. As well, being a mother of college students 
also meted out a type of kinship to those of my participants' age. Understanding this setting with an emic viewpoint was not wholly difficult from the educator and matriarchal points of view, but having said that, my aim was to remain objective and be able to explain the setting and dynamics to outsiders (Merriam, 2009, p. 126). An important notation here is that all participant and location names in this study, including cities, states, schools, and departments included in this study are named by pseudonyms for the purposes of anonymity, as directed by Midwestern University's Review Board and the Director of the Academic Center.

\section{Data Collection and Analysis}

This observation occurred from 1:00-2:15 in an Academic Center on the campus of Midwestern University in the United States. The specific observation locale was a classroom with fifteen students present, as well as one teacher, one peer instructor, and one observer. The demographics of the students in this class were two females and thirteen males; specifically one Asian (in appearance) female, one white female, five Asian (in appearance) males, one African-American male, and seven white males. The students were freshmen and sophomores, ages nineteen and twenty. The teacher was a white, Englishspeaking, American male, age 27, and the lone peer instructor was an African-American junior at this Midwestern University, age 21.

\section{Participant Codes for the Observation}

MWPTStudent $=$ Male, White, Pony-tailed Student

FAAStudent $=$ Female, African-American Student

FAStudent $=$ Female, Asian Student

MWSSNDoor $=$ Male, White Student Seated Nearest Door

MAStudent $=$ Male, Asian Student

MRSSASSudent $=$ Male, Red Shirt, Short Attention Span Student

MSDIHTRStudent = Male, Self-Designated 'I Hate To Read Student'

*A pseudonym was used to protect the identity of this male, white student.

MABHWStudent = Male, Asian, Baseball Hat-Wearing Student

1:00 P.M.

When the students entered the room, the atmosphere felt a bit "tight,"' as if the students were nervous about their upcoming homework presentations. To loosen up the classroom's atmosphere, the teacher reached out to his pupils:

Teacher: "Does anyone have a favorite song they would like to listen to before class starts?"

MWPTStudent: (a soft-spoken, long-legged, blonde, pony-tailed young man piped up) "My band just uploaded a new song and video on YouTube."

Teacher: "What's the address?" (looking at the student who suggested the video)

Observer: "Can somebody turn down the lights so we can better see the video?" (The observer spoke in the direction of students sitting next to the light switches.)

[OC (observer comment): The pony-tailed student glanced over at me and smiled; we all proceeded to watch his three minute and twelve second, black and white, quick-spliced, raging musical tale of self-evolution. The member of the class was the band's featured lead guitarist, whose talent was 
prominently heard in the video and visually easy to discern as his loosened hair wagged to and fro when he head-banged with the beat. As the lights came up and class commenced, the guitarist with the Batman bracelet and red Converse tennis shoes looked over at me and grinned; I gave him a thumbs-up.]

\section{1:16 P.M.}

At the conclusion of a ten-minute Ted Talks video about the science of motivation and how if/then motivational "carrots" do not work:

Teacher: "So, after viewing this video, what do you take away from this message?" (For a few uncomfortable seconds, no one raised their hands; after about ten more seconds, the teacher elaborated his inquiry.)

Teacher: "What do you feel about what the speaker said about goal setting?" (An immediate, odd silence came over the room, as if the students felt collectively awkward as they all stared at their shoes and/or the floor.)

Teacher: "Well, goals need to be short-term and long-term. For example, an appropriate long-term goal for you all is that you would have the date of the last day of the semester in your minds. A good short-term goal would be to get off academic probation this semester."

Teacher: (at this juncture the teacher began gesturing and explaining) "Let's break into small groups of three, count off by threes, and move the desks, please, to be closer in proximity."

[OC: At this point, it seemed evident that the teacher's choice of video clip was a very effective one based on the fact that his class's lack of motivation was a possible cause of their low GPAs. One thing that surprised me during this observation was the level of intelligence of the students, as indicated by their responses in class. My misguided preobservation expectation was that on academic probation, the students might manifest as uninterested or dull. This was not the case; in fact, most of the students were quite active in their participation level with a myriad of qualified, intuitive answers for their teacher. This experience was a good reminder to me to leave preconceived notions at home.]

\section{1:34 P.M.}

Teacher: (once the groups were broken into groups) "Who can explain what outlining is?"

MWSSN: (raising his hand in reply) "An outline can be specific or not, depending on what you want to do."

Teacher: "Good! Anybody else?" (to the rest of the class)

Teacher: (to garner answers from everyone, the teacher then said) "Okay, let's go around the room."

[OC: starting at one side of the horseshoe of student desks, moving from left to right, student by student, skipping over those who had previously offered an answer, the teacher expected participation from every student.]

MAS: "I prefer ... not to answer." (with his head down, as if he were not prepared to answer)

\section{2:02 P.M.}

Teacher: "Does anyone have a question about the assignments due on Thursday?" (no one raised their hand) 
Teacher: (to the class) "In that case, class is over. Jed (pseudonym used), I need to speak with you before you leave today."

[OC: Just then, two students approached the teacher's computer desk setup with trepidation, as if they were nervous. One was a male Asian (in appearance) student, and the other was an Asian (in appearance) female who had slid into the room after class started (possibly a girlfriend of the student?)]

MABHWStudent: "Why did I lose so many points on ... assignment?"

Teacher: (Quietly, the teacher pulled up the X158 syllabus on the computer to show it to the student.) "If you look here at the syllabus, it says that the assignment must be at least 250 words and yours was 150 words. That's why you had points deducted."

MABHWStudent: (pausing for a long minute, looking down at his feet and then glancing up, not quite into the eyes of the teacher) "What does 'at least' mean?"

Teacher: (patiently explaining) "At least means writing at least 250 words or more.”

MABHWStudent:_(nodding slowly, backing out of the room) "Okay."

\section{2:21 P.M.}

End of Observation

After twelve weeks of researcher whole-class observations, six participant interviews, and one formal teacher interview, along with virtually daily unstructured teacher email questions, two peer instructor interviews, as well as unstructured, informal meetings with the Director and Academic Coordinator of The Academic Center during the Spring 2014 semester, the results of this research produced interesting findings. All interviews were collected onsite, at The Academic Center and the researcher observations were completed in the classroom on the second floor of the same building. This ethnographic, qualitative study of three student members of an academic probation required class included: one female (a freshman) and two males (one freshman and one transfer student/sophomore) and one junior peer instructor/student (none of whom had learning disabilities as established by individualized educational learning plans). All participants in this study were interviewed through an audio-record format in an interviewer/ participant voluntary agreement.

After establishing a researcher-observer presence over a twelve week period, at the end of class one afternoon, I made a brief, five-minute appeal to the entire group of students as to the nature of my project and requested interview volunteers. To my delight, three students immediately volunteered. These interview sources were key and primary in that they were the originators of my data. They recounted to me firsthand their personal, family, and school experiences contributing to their academic experiences prior to coming to college and while at college during their freshman year. I adhered to Robert Weiss's (1994) interview methodology, in that an uninhibited flow of participant response to researcher inquiry is "better" than demanding strict adherence to a list of predetermined interview questions (p. 78). 


\section{Participant \#1/Anastasia}

My first participant interview was with a second-semester sophomore, Anastasia (her chosen pseudonym). During the initial part of the interview, I learned that Anastasia had a painful family history of living in three foster homes, living alone in a car in the seventeenth year of her life, and finally living completely on her own, working fulltime at an elder-care center, and attending college fulltime at the age of nineteen. An amazingly eloquent and gentle young woman, my awe at her life story was trumped only by my respect at her early maturity and persevering spirit. Just before the formal interview began to be recorded, I asked her informally, in an unstructured manner, about her leadership skills in class and her amazing command of high-level vocabulary and critical thinking skills I had observed. Her response to my query set the tone for the interview, and while not recorded as part of the transcript, needs to be scored as a key component of her background demographics.

Anastasia explained to me that during her life between the ages of twelve to fifteen, she lived with her father in small, random cities in Texas in a transient lifestyle. Her father welcomed no friends or acquaintances into Anastasia's living quarters and her father demanded they live a more or less hidden life (her words). Because of this, she said she excelled in high school and was always on the high Honor Roll, as she spent most of her time outside school in free public libraries where she could dwell largely unnoticed and have access to free books; Anastasia related to me that she spent many hours after school each day and weekends alone, doing her homework and reading books in libraries. She indicated that this circumstance was the source of the vocabulary development I had noticed. After this eye-opening explanation, she smiled, and I turned on the recorder in a small, private room on the second floor of The Academic Center at Midwestern University on Davis Street and my excursion into the world of underperforming college students began in earnest.

\section{Transcript of Interview with Anastasia/P (Participant \#1) and Melissa/I (Interviewer)}

Melissa/I: Please tell me about your early college experience.

Anastasia/P: I had my first job when I was fourteen. I've always worked for what I've had, and I've always paid for my stuff. As soon as I graduated in March and I turned eighteen in February, I moved into my own apartment and I've lived there the last two years. So I have my own apartment a couple of miles from campus. And I do that, and I work full time, and I go to school.

Melissa/I: Wow. Where do you work?

Anastasia/P: I work at Comfort Is Yours (pseudonym). It's a nonmedical elderly care.

Melissa/I: You are paying for all your living expenses and your tuition. I don't even know how you do that.

Anastasia/P: It's hard. I saved up a lot from working a lot throughout high school. I would put half of my check aside from every paycheck. To pay for a car when I got a car and that's how I was able to move out. [She lived in this car for one year.] I still do this on a smaller scale but obviously I can't afford to put half of my paycheck in savings. But I have an automatic setup so money is automatically transferred into my savings account. I make sure that I am very conscientious of my 
spending and what I do and what I don't do. Also, because I pay for my books and everything, but I also get a grant. My aunt, she had Power of Attorney over me. So when I filled out my FAFSA, she was no longer my legal guardian. Because of that situation I was accountable for myself, so I didn't have to worry about my parents' income and even if I had, my dad hasn't worked in the last 30 years and my mom is disabled so I couldn't really count their income for anything. So I was able to get a grant because of the financial situation, because it was only based on my income, which at the time was very little.

Melissa/I: So what happened academically when you first entered Midwestern University?

Anastasia/P: So, I did each semester my first year and worked full time and I did okay. So, even though I did really well academically in high school I had a hard time trying to balance everything, and I got C's and B's and I did fine for the first year. And then first semester of the second year, I was working at my job at the same rate, but taking 15 credit hours, because I was trying to catch up, so I could catch up so I could graduate when I wanted to.

Melissa/I: Right! I understand what you are saying.

Anastasia/P: I would have been doing alright, but it was so hard to balance, and I was also in a relationship that negatively impacted me. It is my nature to be helpful, and so I always think of others before I think of myself. I was way too giving and naïve, and so I dealt with guy trouble, but that's pretty normal. It's just not great when you're working and going to school, and throwing that in the mix and so, basically what happened was that he quit his job and I supported him for a month. Then I ended up having car problems and I ended up being in the hole myself. I had to get myself back financially stable. So it was pretty much like a trifecta of things, my academics were suffering, my finances were suffering, and my emotions were suffering, because of this relationship. I was able to get out of that, but even though I was able to get B's and A's towards the end of the semester, it wasn't enough to pull me up from getting C's and D's in a couple of my classes. Because I got D's in a couple of my classes, my GPA dropped to a 1.9. That was extremely unfortunate, because the rule at Midwestern University is that if your GPA is under 2.0, you are on Academic Probation. So, when I found out I had to take the class for students on academic probation, and that my GPA was just under 2.0, I was really disappointed in myself.

Melissa/I: Okay.

Anastasia/P: So my confidence faltered because the shift in my grades, because once you take someone who has this thing so attached to their social schema, when that changes, it causes an effect there.

Melissa/I: Well, too, because this happened at your age it's difficult to handle.

Anastasia/P: So I was at the point when I found out that my GPA had suffered and it really got to me because I felt worried because I want to keep going to Midwestern University because it is something that I want to do, because you know, I'm used to a bit of a lifestyle. Of course you know, I'm used to living in my apartment and I have cats, and I have comfort and the privilege to be at Midwestern University. Being able to have an apartment and my independence and freedom, because I've always been an independent person .... is important to me. I didn't want to sacrifice that, and I thought that if I wasn't able to get through this bump with the probation, then it would make things much harder for me ...

Melissa/I: Right.

Melissa/I: How do you feel now about your ability to earn good grades and move forward with your goals? 
Anastasia/P: In my Cognitive Psychology class, I have a ' $\mathrm{B}$ ' but the way he asks the questions is really complicated for me. I study very much for his tests and then I go in and his question is 2 paragraphs long and I am thinking, 'I know what you're asking me but it's difficult because of the way that it's worded.' Because he has this specific way that he wants to do things .... I understand that he has been teaching longer than I have been taking Cognitive Psychology, but I find that there are certain teachers that have a very specific way of doing things that is different from the norm. It's challenging because the way he does things is so different for me. You know, it's four tests and some of them drop one of the tests. And he drops a grade as well but his is more accelerated because we have a test every 2 weeks it seems. It's maybe a little longer between that, the way that he does his tests is that he does it in parts; a lot of it is from slides. So when you take the test, he wants you to answer in the way that he explained it. And that's in addition to the book and everything else.

\section{End of Anastasia/Melissa Excerpt of Transcripted Interview}

Seven major themes contributing to academic underachievement emerged from the participant interview with Anastasia: first and second, familial drama and strife caused an almost insurmountable financial and emotional hindrance to college academic success. Third, time management issues related to her need to work to support herself, and fourth, relationship drama (in this case that of a boyfriend) took focus away from studying and thus college academic success. Fifth, a resulting lack of confidence that emerged after Anastasia experienced trying to successfully balance supporting herself financially, and attending college, while working full time. Sixth, a fear of failure related to a fear of change in her standard of living, and finally seventh, a lack of proper testing skills preparation for college-level tests. On this note, she specified that she did not command the ability to synthesize large quantities of reading and provide essay style answers to paragraph-long questions.

\section{Participant \#2/Gabe}

My second participant interview was with a second-semester freshman, Gabe (his chosen pseudonym). Gabe is a first generation college student, and was from a family whose men worked in the steel mills of Blytheville, Arkansas. He attended public high school and transferred several AP classes to begin his freshman year.

\section{Transcript of Interview with Gabe/P (Participant \#2) and Melissa/I (Interviewer)}

Melissa/I: Tell me about your classes during your first semester at Midwestern University.

Gabe/P: Well, Introduction to Psychology probably would have been easy, if I had gone to class.

Melissa/I: Oh, yeah.

Gabe/P: I got a $\mathrm{C}$ without going to class.

Melissa/I: Did you not go to class because it was early, or you just didn't want to?

Gabe/P: I go to all my classes now; that one was pretty early for me.

Melissa/I: So how did you rationalize to yourself missing class?

Gabe/P: I stopped going to most of my classes except my Sociology because I kind of enjoyed it, and we had an attendance policy in that class. I did not have an attendance policy in the rest of my classes. The first month was easy, or I thought it was easy, so I decided not to go. I didn't stop going all together; I would just skip one day a week. As the semester progressed, it became two days out of the week, and then sometime I stopped going to class altogether. You skip one day and it's no big deal, and then you keep doing it. 
Melissa/I: Now how does that work? When you don't go to class, what are you doing? Are you sleeping, drinking, and watching TV, or what are you doing?

Gabe/P: During my Psychology classes, I was usually sleeping, because it was early. During my Calculus class, I would usually just sit around and do nothing and hang out. During my K201 class, I signed up for it at 4:00 and they moved it to 8:00 p.m. So, either I just didn't feel like going because I was already settled in for the night, or I just was hanging out with my friends.

Melissa/I: Dude, if you can get a C in Psychology without attending class, that's a sign: You are capable of attending college. So how do you feel now that you are on academic probation? It sounds like you held on pretty well, without even going to class. Do you feel like you want to stay in college; do you want to stay here?

Gabe/P: Yes, I definitely want to stay here. When I first got here ... what happened to me last semester really questioned the value of college for me.

Melissa/I: Sure, that is not unusual.

Gabe/P: I really began to have a negative attitude. It was especially about my Calc class and that was the one I was doing really badly in and that was because I wasn't even going to class. I decided I don't want to sit at this desk, I don't want to be a cog in a machine, but then I began to realize: what was I going to do outside of college? You know that normal college thing. If I left after this semester, what was I really going to do? It was either this, go work in the mill, or work at some dead-end job.

Melissa/I: So your Grandpa worked at the mill?

Gabe/P: Yeah. That's where my Grandpa worked. It was either this or the steel mill and I definitely did not want to do that.

Melissa/I: Now sometimes, freshmen get into alcohol or drugs or sex excessively when they come to college. Was there anything like that that really got you off track?

Gabe/P: In high school I drank quite a bit. Actually, right before college, I got into an accident and broke my collarbone. After that, I definitely cut down a lot on how much I drank. When I came to college, I started smoking marijuana. I smoked weed back in high school, but my first semester here, I smoked a lot. Well, actually, that really had an effect on me. I had to stop that, because it was making me stop going to class. Marijuana really kills your ambition. My friends are like "Oh come on, you can do it," and I had to tell them," Oh no man, I can't." I had to stop that altogether.

Melissa/I: I think you have found a really good strength from within now. When you get this report card, and it's so much better than your first semester at Midwestern University, you really need to pause and consider the difference.

Gabe/P: Yes, I feel good about it. First semester, I hated college. Now I love it here.

Melissa/I: In the environment where you grew up, was there pressure that you should go to college?

Gabe/P: It's kind of a weird thing. I was raised by my father and he married my stepmom when I was in the third grade. My dad went to college for a year and he flunked out. Then I think he went back, but he had me at age 21 , and he had to drop out. There was always "Go to college if you want." He told me that I would have a better life if I went to college.

Melissa/I: Well, that's good. That's positive. So what made you want to go to college, what made you think "I really want to go to college?" 
Gabe/P: I think it was just because from a young age, from people in general, you are told you are supposed to go to college. I don't want to sound conceited, but I am smart. I did well, but I am just horribly lazy.

Melissa/I: So what do you think about that? What did you think when you were advised you were going to have to study about three hours a day when you came to college?

Gabe/P: I came in with the attitude that it was going to be high school all over again, but that I did not have to go to class. Because, I mean, in high school, I never did homework. Until junior year, I almost never did homework, and I would just ace tests. The only time I did homework is if I had to write a paper. If I had to write a paper or do a project where I had to work on it in advance, I would. If it was something like to do an assignment or homework, I never did it and I would at least pull a B. There were a few times when I didn't do as well on a test as I should, but most of the time I would get a B or an A.

Melissa/I: Without doing any homework.

Gabe/P: At the time, I thought I would be able to do that in college and everyone told me, "No you are not going to be able to do that." I have cousins who came here, and they were all like, "No you can't do that." And I said, "No, I will be able to do that." For the first half of the semester, I thought I was going to do it, but as I stopped going to class more frequently, I kind of had the sense that I needed to go to class, but I pushed it in the back of my mind. As the days got closer to the end, I said, "Oh, this is not good." And then taking that final that you didn't study for, like I didn't study for my Calculus final, you are thinking .... I'm failing this class, I'm gonna fail it. You know something has definitely gotta change.

Melissa/I: Well, that's good that you realized something had to change.

Gabe/P: Well, I wish I weren't as hard-headed as I am. I should have realized it sooner when people told me what I should have done ... it would have been a different ball game.

\section{End of Gabe/Melissa Excerpt of Transcripted Interview}

Seven significant themes contributing to academic underperformance emerged from the participant interview with Gabe: first, lack of class attendance; second, a "why am I attending college in the first place" identity crisis occurrence; and third, a realization that he did not want the job options available to him without the benefit that a college graduation would afford him. The fourth and fifth themes that can be attributed to Gabe's underachievement during his first semester in college were use of marijuana (which he indicated lessened his ambition to study and go to class) and inadequate study time. Themes six and seven of Gabe's narrative involved struggles related to being a firstgeneration college student and a lack of effort or self-proclaimed lazy work ethic.

\section{Participant \#3/Neff}

My third participant interview was with a second-semester sophomore, Neff (his chosen pseudonym). Neff is an Exercise Science major, who completed his first year of college at State University with the intention of completing his prerequisites at a less expensive location and then transferring to Midwestern University. His other reason for staying home his freshman year in college is that his parents were going through a divorce and he needed to be at home for family reasons. 


\section{Transcript of Interview with Neff/P (Participant \#3) and Melissa/I (Interviewer)}

Melissa/I: What would you say were some of the difficulties you experienced that caused you to be on academic probation this semester at Midwestern University?

Neff/P: Transitioning from the college where I started, to the academic environment at Midwestern University was difficult, most definitely. You know there is a "stereotypical" situation of a house in college, but that just doesn't apply to me. On weekends we can have fun, but on weekdays, that just doesn't happen.

Melissa/I: That's good.

Neff/P: Yeah. Ah, I would say generally that's not the issue. One of the biggest issues was the transition of coursework and the sense of why exactly am I here? Which is why I feel like a lot of kids lose interest and start declining in grades. You start doing all this work and everything is thrown at you and you get stressed. You are not going to hold up if you are not studying something that you actually want to do. My issue was I started beating myself up thinking, "You are probably not gonna do very well. You don't really know why you are here, or what you are doing." That, in my opinion, is what got me here on academic probation.

Neff/P: I made the mistake of taking two history courses in the same semester, which between those two had fifteen hours of reading a week. Just those two classes required that much study time, and I had three other classes, which I was neglecting because of the two history classes.

Melissa/I: Oh, wow!

Neff/P: That was overwhelming because the one had papers due that were assignments with citations due every week. Yeah, my course load going from IPFW to that was rough. And the other course I took last semester, Diseases in the Human Body, which I am retaking this semester, has only 4 tests. There is no homework, there is no midterm, there are just four tests and that's what you do. So it's pretty difficult as well.

Neff/P: I found myself overwhelmed with how much was going on. It was not like that at IPFW at all. That was a huge thing with me last semester. You don't do well on a homework assignment and then you don't want to go to class because you didn't do well on your assignment and you start to beat yourself up because you don't want to be there. It is just sort of a downward spiral which I've definitely broken that habit. It doesn't really matter what you get on any one thing.

Melissa/I: A few people have said that they felt overwhelmed that not any individual class was super difficult but dealing with everything at once was complicated ...

Neff/P: Really, students are given complete freedom here for the most part, and we had to ask to use the bathroom the year before! That's if anything I would say what would have been really helpful like to have to take some first year student class-but an honest one, a real one that was almost like a real study table. Like, there would be peer advisors there helping you get used to the idea that everyone has to study this much. You can convince yourself that you don't have to study as much as you need to, and then you end up on probation.

Melissa/I: So, do I hear you saying it's hard to get your mind around the idea that you have to study three hours a day, seven days a week, at a minimum, just to stay even?

Neff/P: Yes, that's a real number, which I didn't believe. I always thought that was an exaggeration but if you want to do well you have to put the time in.

Melissa/I: That's great. Earlier you said your parents were split up. Was going to college your parents' idea for you, or was that your idea? 
Neff/P: I would say that is the culture of my private high school. I think we had $99.9 \%$ graduation rate and that's what everybody does; they go to college. What I found is that, what I want to do in the future, I needed college.

Melissa/I: How did you decide what to take as a transfer student?

Neff/P: There were so many kids going through freshman orientation and I was a transfer student and there weren't very many classes to choose from. Last semester's schedule was something my advisor and I put together with what we had to use.

Neff/P: Another thing that caused me to end up on academic probation was dealing with anxiety in the classroom. Sometimes the room-during a test especially-feels really small and I just have out get out of there. That was a huge problem for me last semester. I would start sweating and my pulse would be outrageous; this semester is better. A big thing for me was tests. If we were all crammed in a small room taking the test, I would start sweating; I would freak out, start breathing heavily, almost start hyperventilating. Tests this semester were in really big rooms and we were really spread out, so I handled them much better.

\section{End of Neff/Melissa Excerpt of Transcripted Interview}

According to Neff, eight intermingled and complicated themes culminated to produce his academic underachievement: first, a lack of experience handling a heavy reading requirement as part of a large comprehensive body of work due weekly. Second, an undercurrent of confidence erosion due to his inability to manage the severe work load, and third, a nagging identity crisis not unusual in college students as to their purpose in studying their chosen major. Two additional themes of struggle Neff dealt with concurrently during his transition year to Midwestern University were the realization that he had to graduate from college to pursue the lifestyle he desired after the college years, as well as transfer student difficulties in available class choices. Unmanaged testing anxiety also became an issue for Neff as he struggled to cope in small testing accommodations. For Neff, time management issues in combination with too much freedom resulted in a breeding ground for underperformance.

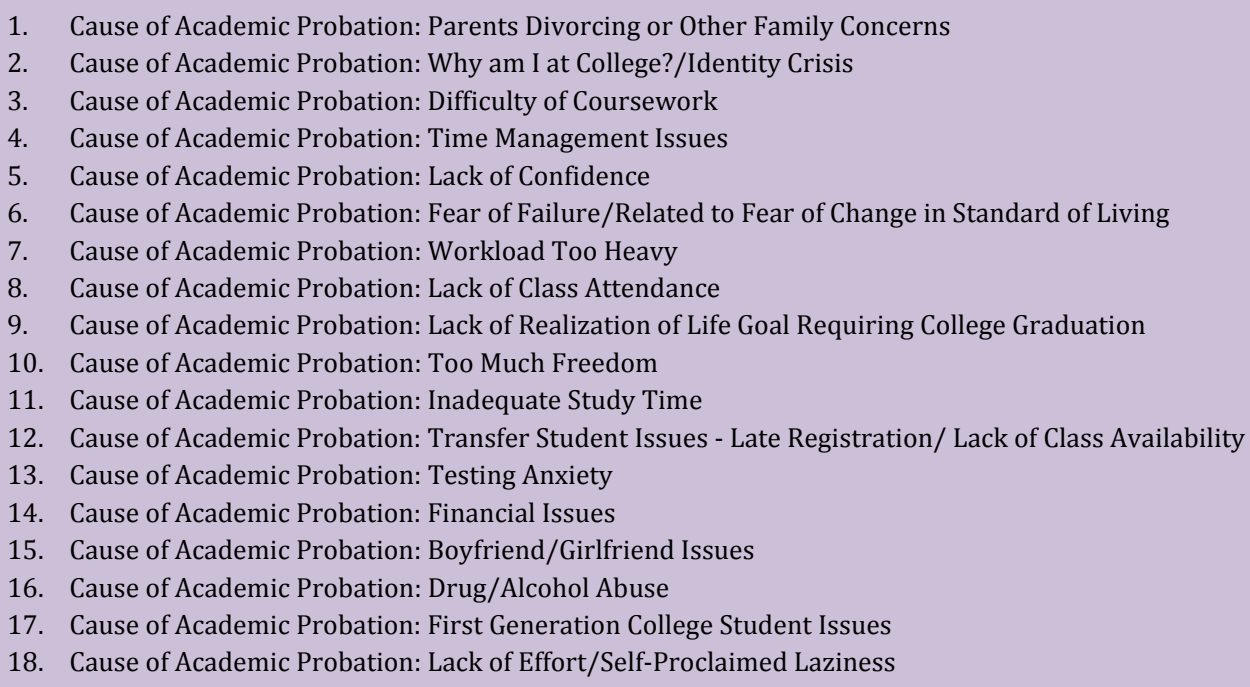

Table 1. Participant Interview Themes/Codes Generated From Explanations as to Why She/He Underperformed During the Freshman or Sophomore Year 


\begin{tabular}{|c|c|c|c|}
\hline $\begin{array}{l}\text { Participant Rationales For } \\
\text { Being on Academic Probation }\end{array}$ & P1/Anastasia & P2/Gabe & P3/Neff \\
\hline Financial Issues & $\mathrm{X}$ & & \\
\hline Boyfriend/Girlfriend Issues & $\mathrm{X}$ & & \\
\hline Difficulty of Coursework & $\mathrm{X}$ & & \\
\hline Time Management Issues & $\mathrm{X}$ & & $\mathrm{X}$ \\
\hline $\begin{array}{l}\text { Fear of Failure/Related to Fear of Change in Standard } \\
\text { of Living }\end{array}$ & $\mathrm{X}$ & & \\
\hline Parents Divorcing or Other Family Issues & $\mathrm{X}$ & & \\
\hline Lack of Confidence & $\mathrm{X}$ & & $\mathrm{X}$ \\
\hline Drug/Alcohol Abuse & & $\mathrm{X}$ & \\
\hline Lack of Class Attendance & & $\mathrm{X}$ & \\
\hline Realization of Life Goal Requiring College Graduation & & $\mathrm{X}$ & $\mathrm{X}$ \\
\hline Why Am I At College/ Identity Crisis & & $\mathrm{X}$ & $\mathrm{X}$ \\
\hline Lack of Effort/Self-Proclaimed Laziness & & $\mathrm{X}$ & \\
\hline First Generation College Student Issues & & $\mathrm{X}$ & \\
\hline Transfer Student-Late Registration/Lack of Class Availability & & & $X$ \\
\hline Testing Anxiety & & & $\mathrm{X}$ \\
\hline Inadequate Study Time & & $X$ & \\
\hline Workload Too Heavy & & & $\mathrm{X}$ \\
\hline Too Much Freedom & & & $\mathrm{X}$ \\
\hline
\end{tabular}

Table 2. Comparative Table Establishing Patterns of Participant Rationales/Causes of Beginning College Students' Academic Struggles

\section{Discussion}

In this small-scale ethnographic project, I opted to limit my qualitative analysis to three participants' multithemed interviews. The participants in this study illuminated eighteen different reasons why they struggled academically and ended up on academic probation at this Midwestern University. Interestingly, and perhaps most surprisingly to me, was that each participant indicated no less than seven legitimate, simultaneous, commingling causes for their underperformance. As well, the participants' reasons for being on academic probation were spread across all eighteen data base indicators in the collection (among all structured and unstructured interview sources collectively) with only four instances of crossover. The repeated rationales indicated by two of three participants were time management issues, lack of confidence, lack of realization that his life career goal required college graduation, and "why am I at college" identity crises.

The initial point this information suggests is that students on academic probation have a myriad of reasons why they experienced this academic difficulty. The following idea arose while synthesizing this small-scale ethnographic research: if students have identifiable reasons why they struggle academically during their first years in college, and if these reasons can be identified over a significant period of time in a substantial quantity of students, universities may do well to offer classes to meet these needs on the basis of retaining these highly sought "customers." After all, many millions of dollars are spent by universities recruiting high school students to attend their campuses, as well as general marketing dollars poured into individual states to create provocative, positive images of a campus's identity. Once a student has chosen a particular university as "theirs" and has 
commenced the endeavor to matriculate, why wouldn't a university's curriculum benefit from offering first- and second-year students classes and support to help ensure their success, based on research that discloses the very stumbling blocks they encounter? A mandatory "Begin with the End in Mind" class or Freshman Seminar for first-semester freshmen and transfer students, focused on the rationales for underperformance from this study, would directly impact and foreseeably decrease the number of beginning college students who struggle academically. After an institution and a student resolve to benefit from a partnership, that relationship should be invested in to promote evolution and ultimate success: graduation.

\section{Implications for Research}

I am inclined to a qualitative, ethnographic methodology of research for the same reasons as Weiss (1994) when he suggests, "We will obtain more reliable information and information easier to interpret if we ask about concrete incidents than we will if we ask about general states or about opinions" (p. 150). The qualitative, ethnographic methodology of this study provides an eagle's-eye view of the living realities of real students who struggle in their initial college academic endeavors. As further study on student underachievement in college broadens through additional interviews and analyses of students on academic probation, implications for research and substantiation of methods of lessening attrition may be enhanced. At the macro level, perhaps this ethnographic data mined through scientific inquiry may stimulate institutions of higher learning to institute proactive, required classes enhancing the opportunity for student success at the college level. At the micro level, this research has allowed me to learn from individual students on academic probation, while affording the opportunity to help them crystallize their academic struggles. Personally, I hope to learn more about the causes of undergraduate academic struggles and what educators like myself can do to change that reality for so many.

\section{References}

Balduf, M. (2009). Underachievement among college students. Journal of Advanced Academics, 20(2), 274-294.

Bourdieu, P. (1992). An invitation to reflexive sociology. (L. Wacquant, Trans.). Oxford: Polity Press. Repr. in M. Grenfell, D. Bloome, C. Hardy, K. Pahl, J. Roswell, \& B. Street (Eds.), (2012). Language, ethnography, and education: Bridging New Literacy Studies and Bourdieu. New York: Routledge.

Carspecken, L. Rationale for triangulation. Class lecture notes, Y611, Indiana University, Bloomington, IN, Apr. 1, 2014.

Coleman, H.L., \& Freedman, A.M. (1996). Effects of a structured group intervention on the achievement of academically at risk undergraduates. Journal of College Student Development, 37, 631-636. 
DeBerard, M.S., Spielmans, G.I., \& Julka, D. C. (2004). Predictors of academic achievement and retention among college freshmen: A longitudinal study. College Student Journal, 38(1), 66-80.

Emerson, R.M., Fretz, R.I., \& Shaw, L. L. (2011). Writing ethnographic fieldnotes (2nd ed.). Chicago: The University of Chicago Press.

Fehrenbach, C.R. (1993). Underachieving gifted students: Intervention programs that work. Roeper Review, 16, 88-90.

Garfinkel, H. (1967). Studies in ethnomethodology. Englewood Cliffs, N.J.: Prentice-Hall. In Emerson, R.M., Fretz, R.I., \& Shaw, L.L. (2011). Writing ethnographic fieldnotes (2nd ed.). Chicago: The University of Chicago Press.

Geertz, C. (1983). Local knowledge: Further essays in interpretive anthropology. New York: Basic Books. In Emerson, R.M., Fretz, R.I., \& Shaw, L. L. (2011). Writing ethnographic fieldnotes ( $2^{\text {nd }}$ ed.). Chicago: The University of Chicago Press.

Grenfell, M., Bloome, D., Hardy, C., Pahl, K., Roswell, J., \& Street, B. (2012). Language, ethnography, and education: Bridging New Literacy Studies and Bourdieu. New York: Routledge.

Haycock, K., \& Huang, S. (2001). Are today's high school graduates ready? Thinking K-16, 5, 3-17.

Hickman, G.P., Bartholomae, S., \& McKenny, P.C. (2000). Influence of parenting styles on the adjustment and academic achievement of traditional college freshmen. Journal of College Student Development, 41(1), 41-54.

Hickman, G.P., Toews, M.L., \& Andrews, D.W. (2001). The differential influence of authoritative parenting on the initial adjustment of male and female traditional college freshmen. Journal of the First-Year Experience \& Students in Transition, 13(1), 23-46.

Hull-Blanks, E., Robinson Kurpius, S.E., Befort, C., Sollenberger, S., Nicpon, M.F., \& Huser, L. (2005). Career goals and retention-related factors among college freshmen. Journal of Career Development, 32(1), 16-30.

LeCompte, M.D., \& Schensul, J. J. (1999). Analyzing \& interpreting ethnographic data. Walnut Creek, CA: AltaMira Press.

Merriam, S.B. (2009). Qualitative research: A guide to design and implementation. San Francisco: Jossey-Bass.

Patton, M.Q. (1990). Qualitative evaluation and research methods (2nd ed.). Newbury Park, CA: Sage Publications.

Ponzetti, J.J. (2012). Loneliness among college students. Family Relations, 39(3), 336-340.

Ryland, E.B., Riodan, R.J., \& Brack, G. (1994). Selected characteristics of high-risk students and their enrollment persistence. Journal of College Student Development, 35(1), 54-58.

Tinto, V. (1987). Leaving college. Chicago: University of Chicago Press. 
Vygotsky, L.S. (1978). Mind in society. Cambridge, MA: Harvard University Press.

Weiss, R.S. (1994). Learning from strangers: The art and method of qualitative interview studies. New York: Free Press. 